Article

\title{
Development, Reproduction, and Life Table Parameters of the Foxglove Aphid, Aulacorthum solani Kaltenbach (Hemiptera: Aphididae), on Soybean at Constant Temperatures
}

\author{
Bo Yoon Seo ${ }^{1}$, Eun Young Kim ${ }^{2}$, Jeong Joon Ahn ${ }^{3}$, Yonggyun Kim ${ }^{4}{ }^{\circ}$, Sungtaeg Kang ${ }^{5}$ \\ and Jin Kyo Jung $2, *$ (i) \\ 1 Crop Protection Division, National Academy of Agricultural Science, Rural Development Administration, \\ Wanju-Gun, Jeollabuk-do 55365, Korea; seoby@korea.kr \\ 2 Crop Cultivation and Environment Research Division, National Institute of Crop Science, Rural \\ Development Administration, Suwon-si, Gyeonggi-do 16429, Korea; key4082@korea.kr \\ 3 Research Institute of Climate Change and Agriculture, National Institute of Horticultural \& Herbal Science, \\ Rural Development Administration, Jeju-si, Jeju-do 63240, Korea; j2ahn33@korea.kr \\ 4 Department of Plant Medicals, Andong National University, Andong-si, Gyeongsangbuk-do 36729, Korea; \\ hosanna@andong.ac.kr \\ 5 College of Biotechnology \& Bioengineering, Dankook University, Cheonan-si, Chungcheongnam-do 31116, \\ Korea; kangst@dankook.ac.kr \\ * Correspondence: jungjk@korea.kr
}

Received: 4 April 2020; Accepted: 8 May 2020; Published: 11 May 2020

\begin{abstract}
We investigated several characteristics of the development and reproduction of the aphid Aulacorthum solani raised on soybean (Glycine max) at 10 constant temperatures between 2.5 and $30^{\circ} \mathrm{C}$, and described the relationship between temperature and several critical biological characteristics using mathematical models. We found that $A$. solani could survive and reproduce on soybean at temperatures ranging from 5 to $27.5^{\circ} \mathrm{C}$. High fecundity was observed at temperatures from 12.5 to $20^{\circ} \mathrm{C}$. The lower developmental threshold and thermal constant for this species' nymphal stages were estimated to be $5.02{ }^{\circ} \mathrm{C}$ and 131.2 degree-days, respectively, using a linear model. The upper developmental threshold was estimated to be $33.9{ }^{\circ} \mathrm{C}$ using the Lactin- 2 model. The optimum temperature for nymphal development was estimated to be $26.9^{\circ} \mathrm{C}$. The maximum total fecundity was estimated as ca. 76.9 nymphs per adult at $18.1{ }^{\circ} \mathrm{C}$. The daily fecundity sharply increased at earlier adult ages, and slowly decreased thereafter until final parthenogenesis occurred, over a range of temperatures from 12.5 to $25^{\circ} \mathrm{C}$. The maximum daily fecundity was estimated to be ca. 6.1 nymphs per adult per day for a 5.2 day old of adult at $21.3^{\circ} \mathrm{C}$ using an age- and temperature-dependent model of adult fecundity. In terms of life table statistics, the intrinsic rates of increase and the finite rate of increase were both highest at $25^{\circ} \mathrm{C}$, while the net reproductive rate was highest at $20^{\circ} \mathrm{C}$.
\end{abstract}

Keywords: Glycine max; Aulacorthum solani; temperature; development; reproduction; life table

\section{Introduction}

The foxglove aphid, Aulacorthum solani (Hemiptera: Aphididae), is a highly polyphagous insect. The number of host plants on which it can feed is as high as 540 identified species (or 688, including unidentified ones) from 33 orders and 82 families throughout the world; in Korea, it has been recorded to feed on 26 (identified) and up to a maximum of 30 plant species (including unidentified ones) from 10 orders and 13 families [1]. This aphid is a major pest of soybean, Glycine max L. (Fabaceae), in Korea and Japan. It mainly feeds on the backsides of soybean leaves, and causes reduced yields 
of soybean through virus transmission and directly sucking out leaf fluids, as well as severe leaf yellowing [2-4]. This aphid occurs on plants from the seedling stage onward during the early summer season in Korean soybean fields, and its density in fields usually reaches maximum values during the fall, in the last half-season of the soybean's reproductive stage. In the results of two sequential scouting studies, maximum densities in September in Korea were recorded as ca. 4300 aphids per 20 hills [2] or ca. 7.4 aphids per leaf [5].

The aphid can develop through both holocyclic and anholocyclic life cycles. The insect overwinters as eggs in the holocyclic cycle, or as nymphs or adults in the anholocyclic cycle on various host plants [6-9]. A. solani is a species that is better adapted to low temperatures than insects in other orders, like many other aphid species [10]. Temperature is one of the most important abiotic factors impacting developmental and reproductive processes in insects because they are poikilotherms, and it affects their survival, population dynamics, and distributions [11]. Many studies, therefore, have focused on the relationship between temperature and development in insect species [12-14].

A few studies have described experiments examining the effects of temperature on the development and reproduction of $A$. solani at multiple temperatures (ranging from low to high ones), derived general relationships between temperature and its development, and constructed life tables for the species when reared on lettuce (Lactuca sativa L.) (Asterales: Asteraceae) [15-19] and pansy (Viola $\times$ wittrockiana) (Malpighiales: Violaceae) [20]. However, only one previous study investigated some biological properties of the development and reproduction of $A$. solani on soybean at multiple temperatures between 10 and $35^{\circ} \mathrm{C}$, and did not perform statistical analyses on their data [2]. Kingsolver et al. [21] pointed out that mean thermal performance can differ in fluctuating and constant thermal environments. They showed that Manduca sexta L. larvae reared in diurnally fluctuating temperatures had significantly higher optimal temperatures and maximal growth rates than larvae reared in constant temperatures. Considering constant temperature has the advantage of allowing direct effects of temperature on the development, longevity, and fecundity of insects to be measured.

Therefore, in this study, we used a wider range of temperatures, from 2.5 to $30^{\circ} \mathrm{C}$, in order to (1) investigate the developmental characteristics of $A$. solani on soybean at different temperatures; (2) describe the generalized relationships between temperature and biological traits, development, and fecundity in this species using mathematical models commonly used in arthropod species; and (3) construct life tables for this species to understand the biological characteristics when reared on soybean. We used the traditional age-specific life table and the age-stage, two-sex life table developed by Chi and Liu [22] and Chi [23]. Although A. solani populations are parthenogenetic, we applied the age-stage, two-sex life table to precisely present the stage differentiation among individuals and then used the life tables to project the population growth at different temperatures. The results of this study can support future studies of this aphid's population phenology, adaptation to climate change, and performance on different soybean cultivars.

\section{Materials and Methods}

\subsection{Insect Colony}

Nymphs and adults of $A$. solani were collected from soybean fields in Suwon, Korea, in 2014, and non-parasitized clones were selected through individual rearing in the laboratory. The clones were combined and reared successively on seedlings of the soybean cultivar Taegwangkong in an acrylic plastic cage ( $27.5 \mathrm{~cm}$ width $\times 30 \mathrm{~cm}$ depth $\times 40 \mathrm{~cm}$ height) in a plant growth chamber. The environmental conditions of the chamber were maintained at $20 \pm 3{ }^{\circ} \mathrm{C}$ temperature, $15: 9 \mathrm{~h}$ (light:dark) photoperiod, and $60 \% \pm 15 \%$ relative humidity. During successive rearing processes, a small proportion of alate form was observed depending on density.

Several apterous adults in the rearing colony were transferred to soybean leaves in Petri dishes (50 $\mathrm{mm}$ diameter $\times 15 \mathrm{~mm}$ height) held in the same rearing conditions, and then nymphs newly born on the next day (after ca. $24 \mathrm{~h}$ ) were used for rearing experiments at different temperatures. 
For adult experiments at $30^{\circ} \mathrm{C}$ only, late-instar nymphs from the rearing colony were transferred to soybean leaves in other Petri dishes, and the apterous adults that emerged the next day were used. Experiments were conducted during the period from 2015 to 2017.

\subsection{Investigation of Nymph Development and Adult Reproduction at Constant Temperatures}

Ten constant temperatures $\left(2.5,5.0,7.5,10.0,12.5,15.0,20.0,25.0,27.5\right.$, and $\left.30^{\circ} \mathrm{C}\right)$ were examined, with aphids in each temperature treatment held at the same photoperiod (15:9 $\mathrm{h}=$ light:dark). A low-temperature incubator (Dasol Ltd., Suwon, Korea) was used to rear aphids at temperatures from 2.5 to $15^{\circ} \mathrm{C}$, while a four-chamber incubator (Dasol Ltd., Suwon, Korea) was used for rearing at all other temperatures. Each neonate nymph was reared on a single leaf of soybean (cultivar Taegwangkong) within a polystyrene Petri dish (50 $\mathrm{mm}$ diameter $\times 15 \mathrm{~mm}$ height). The petiole of the leaf was wrapped in moistened cotton wool, and small drops of distilled water were applied to the cotton wool every day to maintain the leaf's freshness. Each leaf was exchanged with a new one at 4-7 day intervals. Thirty replicated nymphs were used for each temperature. The occurrence of developmental milestones such as molting, death, and reproduction was recorded daily until death. Neonate nymphs produced from adults were removed immediately after being counted. For the adult experiment at $30{ }^{\circ} \mathrm{C}$, thirty apterous adults were treated without examination of their nymphal stages.

Mean values and standard deviations (SD) for the duration of the total nymphal period, each instar period, adult longevity, pre-reproductive period, reproductive period, total fecundity, and daily fecundity during the reproductive period were calculated. One-way analyses of variance and comparisons of significant differences among different temperatures via Tukey's HSD test $(\alpha=0.05)$ were conducted using the PROC GLM function in the program of SAS Ver. 9.1 [24]. Stage-specific mortality during the nymphal period was calculated as the percentage of the initial number of nymphs present in a stage that later died during that stage (i.e., the number that died divided by the initial number). Reproductive rate was calculated as the percentage of the initial number of adults that produced progeny.

\subsection{Models and Estimation of Parameters}

The characteristics investigated at each temperature were analyzed using several mathematical models that produced development curves similar in shape to the observed data, and containing parameters and derivatives with biological meanings. The parameters of all two-dimensional models were estimated with TableCurve 2D Ver. 5.01 (Systat Software Incorporated, San Jose, USA), while those of the three-dimensional model (Equation (8)) were estimated with TableCurve 3D Ver. 4.0 (Systat Software Incorporated, San Jose, USA).

The relationship between temperature and the development rate of $A$. solani nymphs was modeled using both a linear model and the non-linear Lactin-2 empirical model. Nymphal development rates, $r\left(T_{\mathrm{C}}\right)$, at a given temperature (in $\left.{ }^{\circ} \mathrm{C}\right), T_{\mathcal{C}}$, were calculated as the reciprocals of the individual nymphs developmental periods (days) during the stage; these values were then averaged for each temperature. In the linear model [25] (Equation (1)), only data from the temperature range between 7.5 and 25 ${ }^{\circ} \mathrm{C}$, over which the relationship between temperature ( $x$-axis) and development rate ( $y$-axis) was linear, were used to estimate the model's parameters. In the linear model, the lower development threshold $\left({ }^{\circ} \mathrm{C}\right)(\mathrm{LDT})$ and degree-days (DD) above the LDT required for the completion of development (i.e., the thermal constant) of the nymphal stages were calculated as $-b / a$ and $1 / a$, respectively, based on the parameters in the linear equation as presented below.

$$
r\left(T_{C}\right)=a T_{c}+b
$$


In the nonlinear Lactin-2 model (Equation (2)) [26], data from all temperatures at which development was successfully completed were used to estimate model parameters, where $T_{L}$ is the upper developmental threshold (UDT), $\Delta T$ is the temperature range over which fast physiological breakdown occurs near UDT, and $\lambda$ is a parameter that is derived to make the development curve intersect the abscissa at a suboptimal temperature; the formula for this model is shown below.

$$
r\left(T_{C}\right)=e^{\left(\rho T_{c}\right)}-e^{\left(\rho T_{L}-\frac{T_{L}-T_{c}}{\Delta T}\right)}+\lambda
$$

In this model, the optimal temperature $\left(T_{\text {opt }}\right)$, at which the maximum development rate was predicted to occur, was calculated as $T_{L}-\Delta T$. The LDT was obtained as the approximate $T_{\mathrm{c}}$ value when $r\left(T_{\mathrm{c}}\right)=0$; this calculation was performed with the parameters estimated in Equation (2) using Microsoft Mathematics Version 4.0.

A two-parameter Weibull equation (Equation (3)) was used to model inter-individual differences in the completion of development [14,27]. In this model, $F(x)$ is the cumulative proportion of nymphal development completed at a normalized time, $x$, corresponding to development time divided by the mean developmental period, and $\eta$ and $\beta$ are fitted parameters, as follows.

$$
F(x)=1-e^{-(x / \eta)^{\beta}}
$$

Aging rate, $r\left(A_{\mathrm{C}}\right)$, at a particular temperature, $T$ (in ${ }^{\circ} \mathrm{C}$ ), during the adult stage was calculated as the mean value of the reciprocals of all individual longevities. The temperature-dependent aging rate was fitted with an Eyring model (Equation (4)) previously used for Rhopalosiphum padi (Hemiptera: Aphididae) [28-30], where $a$ and $b$ are fitted parameters as shown below.

$$
r\left(A_{c}\right)=a T e^{-b / T}
$$

The relationship between total fecundity per female and temperature was estimated using Equation (5), proposed by Briere et al. [31].

$$
f(T)=a T\left(T-T_{L}\right)\left(T_{M}-T\right)^{1 / m}
$$

where $f(T)$ is the number of total nymphs laid by one female at each temperature, $T_{L}$ and $T_{M}$ are the lower and higher temperatures for oviposition, and $a$ and $m$ are empirical constants of the equation.

The relationship between cumulative fecundity ratio and the normalized adult age (=adult age/mean adult longevity) was fitted with the two-parameter Weibull model used for describing the completion of nymphal development (Equation (3)) above.

The relationship between cumulative survival ratio, $s(x)$, and the normalized adult age, $x$, was described with a model (Equation (6)) previously used for Carposina sasaki (Lepidoptera: Crambidae) [32], in which $\gamma$ is the normalized age at $50 \%$ cumulative survival rate and $\delta$ is a fitted parameter, as follows.

$$
\mathrm{s}(x)=\frac{1}{1+e^{(\gamma-x) / \delta}}
$$

The relationship between daily fecundity, $y$, and adult age, $x$, at the same temperature was described with an adjusted nonlinear model (Equation (7)) previously used for Myzus persicae (Hemiptera: Aphididae) [33], in which $p_{1}$ is the total fecundity, $p_{2}$ is the mean pre-reproductive period, and $p_{3}$ is a speed constant, as follows.

$$
y=p_{3}^{2} p_{1}\left(x-p_{2}\right) e^{-p_{3}\left(x-p_{2}\right)}
$$


The relationship between temperature, $T$, adult age, $x$, and daily fecundity, $F(x)_{T}$, was described with a model (Equation (8)) previously used for a mite species, Hypoaspis miles (Mesostigmata: Laelapidae) [34], in which $\epsilon, \theta, \kappa, \rho, v$, and $\psi$ are fitted parameters, as shown below.

$$
F(x)_{T}=e^{\left(\epsilon+\theta T^{2}+\kappa T^{3}\right)} x e^{-\left(e^{\left(\rho+v T^{2}+\psi T^{3}\right)}\right) x}
$$

\subsection{Life Table Construction}

Life tables were constructed using the methods described by Jandricic et al. [20], Birch [35] and Southwood and Henderson [36]. Data for the survival, birth, and development of individuals from the neonate nymph stage to death at eight different temperatures between 5 and $27.5{ }^{\circ} \mathrm{C}$ were collected. The age-specific survival rate $\left(l_{x}\right)$ (Equation (9)) and the survival rate $\left(s_{x j}\right)$ were defined to be the probability that a newly born individual would survive to age $x$ and stage $j$, respectively. The $s_{x j}$ provides the beginning age $x$ of the survival curve of stage $j$, last age $x$ of the survival curve of stage $j$, mortality of stage $j$, and death age of individuals that died in stage $j$. The death, the beginning, and end of a stage can be provided.

$$
l_{x}=\sum_{j=1}^{k} S_{x j}
$$

where $k$ is the number of stages.

The age-specific fecundity $\left(b_{x}\right)$ (Equation (10)) was calculated to take individuals of different stages at age $x$ into account. The age-stage-specific fecundity $\left(f_{x j}\right)$ is the number of nymph eggs produced by a female adult at age $x$.

$$
b_{x}=\frac{\sum_{j=1}^{k} S_{x j} f_{x j}}{\sum_{j=1}^{k} S_{x j}}
$$

Net reproductive rate $\left(R_{0}\right)$ was calculated as $R_{O}=\sum_{x=0}^{\infty} l_{x} b_{x}$, being the total number of offspring that an individual can produce during its lifetime. Traditionally, the intrinsic rate of increase $\left(r_{\mathrm{m}}\right)$ was obtained with a Euler equation, $\sum\left[\mathrm{e}^{(-r \mathrm{~m} \times x)} \times l x \times b x\right]$, and, when summed across all ages, the values in this equation added up almost to 1 (calculated to ten decimal points); this calculation was performed using Microsoft Excel (Microsoft Office Professional Plus 2013). The finite rate of increase $(\lambda)$, generation time $(\mathrm{G})$ (in days), and doubling time (DT) (in days) were calculated as $\mathrm{e}^{r \mathrm{~m}}, \mathrm{Log}_{\mathrm{e}}\left(R_{0}\right) / r_{\mathrm{m}}$ and $\log _{\mathrm{e}}(2) / r_{\mathrm{m}}$, respectively.

The life history data of $A$. solani were also analyzed based on the age-stage, two-sex life table theory [22] and the method described by Chi [23] using the computer program TWOSEX-MSChart [37]. The intrinsic rate of increase $(r)$ is calculated using the Euler-Lotka formula (Equation (11)) with age indexed from Day 0 [38], as follows.

$$
\sum_{x=0}^{\infty} e^{-r(x+1)} l_{x} m_{x}=1
$$

The generation time (G) (in days), and doubling time (DT) (in days) were calculated as $\ln \left(R_{0}\right) / r_{\mathrm{m}}$ and $\ln (2) / r_{\mathrm{m}}$, respectively. The statistical differences among different temperatures were analyzed with a paired bootstrap test at the 5\% significance level [39]. The bootstrap method was contained in the computer program TWOSEX-MSChart. The life table data were used to predict and compare the population growth of $A$. solani at different temperatures using the TIMING-MSChart program [40]. The 10 newborn nymphs were the starting point used to simulate the population growth of each temperature. The common logarithm was used to describe the population growth of stage $j$ from time $t$ to $t+1$. 


\section{Results}

\subsection{Nymphal and Adult Development and Fecundity}

Aulacorthum solani nymphs could not complete development to adult emergence at 2.5 or at $30{ }^{\circ} \mathrm{C}$. Their mortality at 5 and $27.5{ }^{\circ} \mathrm{C}$, however, was very low, and had values of $10 \%$ and $0 \%$, respectively. The mortality at $7.5^{\circ} \mathrm{C}$ increased to ca. $23 \%$, but decreased again from $3.3 \%$ to $0 \%$ with increasing temperature. At all temperatures at which nymphs completed development, only four nymphal instars were observed. Nymphs showed high stage-specific mortalities, ca. $73 \%$, in the first instar stage at $2.5^{\circ} \mathrm{C}$, while at $30{ }^{\circ} \mathrm{C}$, they showed a high mortality of $63 \%$ in the second instar. The length of the nymphal period, including the duration of each separate instar, decreased with increasing temperature, but the durations of the first, second, and third instars increased at $30{ }^{\circ} \mathrm{C}$ (Table 1 ).

Adult longevity was longer at lower temperatures over the range of 5.0 to $12.5^{\circ} \mathrm{C}$, and thereafter decreased with increasing temperature; lifespans were shortest ( 3.7 days) at $30{ }^{\circ} \mathrm{C}$. Reproductive rates were high at all temperatures. The length of the pre-reproductive period decreased with increasing temperature from 5 to $25{ }^{\circ} \mathrm{C}$, but then increased slightly at $27.5{ }^{\circ} \mathrm{C}$, and then decreased again at $30^{\circ} \mathrm{C}$. The reproductive period was the longest at 7.5 and $12.5^{\circ} \mathrm{C}$, and it decreased with increasing temperature within the upper range of the temperatures tested. Total fecundity was significantly higher from 12.5 to $20^{\circ} \mathrm{C}$ compared with that at lower and higher temperatures. Mean daily fecundity during the reproductive period was the highest at $20^{\circ} \mathrm{C}$ and $25^{\circ} \mathrm{C}$, with 3.8 and 3.6 nymphs produced per adult per day, respectively, at these temperatures (Table 2). Notably, only one adult out of the thirty apterous adults exposed to $30^{\circ} \mathrm{C}$ changed to the alate form two days after emergence and before death (longevity: 4 days), without undergoing parthenogenesis. 
Table 1. Development duration (days, D) (mean \pm SD) and stage-specific mortality (\%, M) of Aulacorthum solani nymphs on soybean at constant temperatures.

\begin{tabular}{|c|c|c|c|c|c|c|c|c|c|c|c|c|}
\hline \multirow{3}{*}{ Temp $\left({ }^{\circ} \mathrm{C}\right)$} & \multirow{2}{*}{\multicolumn{2}{|c|}{$\begin{array}{l}\text { First Instar } \\
\text { This Study }\end{array}$}} & \multirow{2}{*}{\multicolumn{2}{|c|}{$\begin{array}{c}\text { Second Instar } \\
\text { This Study }\end{array}$}} & \multirow{2}{*}{\multicolumn{2}{|c|}{$\begin{array}{l}\text { Third Instar } \\
\text { This Study }\end{array}$}} & \multirow{2}{*}{\multicolumn{2}{|c|}{$\begin{array}{c}\text { Fourth Instar } \\
\text { This Study }\end{array}$}} & \multicolumn{4}{|c|}{ Total Nymph } \\
\hline & & & & & & & & & \multicolumn{2}{|c|}{ This Study } & \multicolumn{2}{|c|}{ Kim et al. [2] ${ }^{2}$} \\
\hline & D & $\mathbf{M}$ & D & $\mathbf{M}$ & D & $\mathbf{M}$ & $\mathbf{D}$ & $\mathbf{M}$ & D & $\mathbf{M}$ & $\mathrm{D}^{2}$ & $\mathbf{M}^{2}$ \\
\hline 2.5 & $16.9 \pm 6.2 \mathrm{a}^{1}$ & 73.3 & $25.0 \pm 16.5 \mathrm{a}^{1}$ & 62.5 & - & 100.0 & - & - & - & 100.0 & & \\
\hline 5.0 & $9.3 \pm 2.3 b$ & 3.3 & $12.0 \pm 1.3 \mathrm{~b}$ & 3.4 & $13.4 \pm 1.7 \mathrm{a}^{1}$ & 0.0 & $14.3 \pm 2.0 \mathrm{a}^{1}$ & 3.6 & $48.7 \pm 3.4 \mathrm{a}^{1}$ & 10.0 & & \\
\hline 7.5 & $8.9 \pm 2.2 b$ & 3.3 & $10.7 \pm 1.8 \mathrm{~b}$ & 10.3 & $12.0 \pm 5.5 \mathrm{a}$ & 3.8 & $12.3 \pm 1.6 b$ & 8.0 & $42.4 \pm 5.0 \mathrm{~b}$ & 23.3 & & \\
\hline 10.0 & $7.2 \pm 1.1 \mathrm{c}$ & 0.0 & $6.7 \pm 0.6 \mathrm{c}$ & 3.3 & $6.2 \pm 0.4 \mathrm{~b}$ & 0.0 & $7.9 \pm 0.5 c$ & 0.0 & $28.0 \pm 1.1 \mathrm{c}$ & 3.3 & $20.2 \pm 4.5$ & 3.0 \\
\hline 12.5 & $4.1 \pm 0.5 \mathrm{~d}$ & 0.0 & $4.6 \pm 0.5 \mathrm{~cd}$ & 0.0 & $4.6 \pm 0.6 \mathrm{bc}$ & 0.0 & $5.8 \pm 0.6 \mathrm{~d}$ & 0.0 & $19.2 \pm 0.7 \mathrm{~d}$ & 0.0 & & \\
\hline 15.0 & $3.2 \pm 0.6 \mathrm{de}$ & 0.0 & $3.0 \pm 0.3 \mathrm{de}$ & 0.0 & $3.1 \pm 0.4 \mathrm{bcd}$ & 0.0 & $3.7 \pm 0.5 \mathrm{e}$ & 0.0 & $13.0 \pm 0.4 \mathrm{e}$ & 0.0 & $13.4 \pm 2.6$ & 3.0 \\
\hline 20.0 & $2.2 \pm 0.5 \mathrm{ef}$ & 0.0 & $2.1 \pm 0.3 \mathrm{e}$ & 0.0 & $2.0 \pm 0.3 \mathrm{~cd}$ & 0.0 & $2.6 \pm 0.5 \mathrm{f}$ & 0.0 & $8.9 \pm 0.6 \mathrm{f}$ & 0.0 & $7.8 \pm 1.2$ & 0.0 \\
\hline 25.0 & $1.7 \pm 0.5 \mathrm{f}$ & 0.0 & $1.7 \pm 0.5 \mathrm{e}$ & 0.0 & $1.4 \pm 0.5 \mathrm{~d}$ & 0.0 & $1.8 \pm 0.4 \mathrm{~g}$ & 0.0 & $6.5 \pm 0.6 \mathrm{~g}$ & 0.0 & $7.0 \pm 1.0$ & 0.0 \\
\hline 27.5 & $1.6 \pm 0.5 \mathrm{f}$ & 0.0 & $1.4 \pm 0.5 \mathrm{e}$ & 0.0 & $1.3 \pm 0.5 \mathrm{~d}$ & 0.0 & $2.0 \pm 0.3 \mathrm{fg}$ & 0.0 & $6.3 \pm 0.5 \mathrm{~g}$ & 0.0 & & \\
\hline 30.0 & $2.0 \pm 0.9$ ef & 0.0 & $2.1 \pm 0.7 \mathrm{e}$ & 63.3 & $5.0 \mathrm{bc}$ & 90.9 & - & 100.0 & - & 100.0 & - & 100 \\
\hline
\end{tabular}

${ }^{1}$ Thirty neonate nymphs were treated at various temperatures. Different letters within a column indicate statistically significant difference among means by Tukey's HSD test at $\alpha=0.05$. ANOVA results were $F_{9,26}=161.47(p<0.0001)$ for 1 st instar nymph, $F_{9,237}=173.47(p<0.0001)$ for 2 nd, $F_{8,224}=145.79(p<0.0001)$ for 3 rd, $F_{7,221}=707.03(p<0.0001)$ for 4 th, and $F_{7,221}=$ $1,741.79(p<0.0001)$ for total nymphal period. ${ }^{2}$ These data are from soybean in Kim et al. [2], where 20 nymphs were replicated and Paldalkong cultivar was used. 
Table 2. Developmental duration (days) and fecundity of A. solani adults on soybean at constant temperatures.

\begin{tabular}{|c|c|c|c|c|c|c|c|c|c|c|c|}
\hline \multirow{2}{*}{ Temp $\left({ }^{\circ} \mathrm{C}\right)$} & \multirow{2}{*}{ Init. No. ${ }^{1}$} & \multicolumn{2}{|c|}{ Longevity (Day) } & \multirow{2}{*}{$\begin{array}{c}\begin{array}{c}\text { Rep. Rate } \\
(\%)^{3}\end{array} \\
\text { This Study }\end{array}$} & \multirow{2}{*}{ R. No. } & \multirow{2}{*}{$\begin{array}{c}\begin{array}{c}\text { Pre-Reproductive } \\
\text { Period (Day) }\end{array} \\
\text { This Study }\end{array}$} & \multicolumn{2}{|c|}{ Reproductive Period (Day) } & \multicolumn{2}{|c|}{ Total Fecundity (No.) } & \multirow{2}{*}{$\begin{array}{c}\begin{array}{c}\text { Daily } \\
\text { Fecundity }\end{array} \\
\text { This Study }\end{array}$} \\
\hline & & This Study & $\begin{array}{c}\text { Kim et al. } \\
{[2]^{4}}\end{array}$ & & & & This Study & $\begin{array}{c}\text { Kim et al. } \\
{[2]^{4}}\end{array}$ & This Study & $\begin{array}{c}\text { Kim et al. } \\
{[2]^{4}}\end{array}$ & \\
\hline 5.0 & 27 & $52.9 \pm 30.1 b^{5}$ & & 92.6 & 25 & $17.4 \pm 2.7 \mathrm{a}$ & $22.4 \pm 12.1 \mathrm{~b}$ & & $11.8 \pm 5.8$ ef & & $0.6 \pm 0.2 \mathrm{~d}$ \\
\hline 7.5 & 23 & $67.0 \pm 25.3 a$ & & 82.6 & 19 & $12.8 \pm 1.4 \mathrm{~b}$ & $45.9 \pm 19.4 \mathrm{a}$ & & $27.8 \pm 12.4 \mathrm{~d}$ & & $0.6 \pm 0.2 \mathrm{~d}$ \\
\hline 10.0 & 29 & $53.2 \pm 17.8 b$ & $52.6 \pm 26.7$ & 100.0 & 29 & $7.1 \pm 0.8 c$ & $24.5 \pm 9.6 \mathrm{~b}$ & $34.8 \pm 10.4$ & $19.4 \pm 5.2 \mathrm{de}$ & $41.8 \pm 23.6$ & $0.9 \pm 0.3 \mathrm{~d}$ \\
\hline 12.5 & 30 & $65.1 \pm 20.4 \mathrm{ab}$ & & 100.0 & 30 & $4.6 \pm 0.6 \mathrm{~d}$ & $46.0 \pm 12.6 \mathrm{a}$ & & $73.5 \pm 12.9 \mathrm{ab}$ & & $1.7 \pm 0.3 c$ \\
\hline 15.0 & 30 & $33.3 \pm 14.3 c$ & $42.4 \pm 21.4$ & 100.0 & 30 & $2.6 \pm 0.5 \mathrm{e}$ & $28.4 \pm 11.9 \mathrm{~b}$ & $28.7 \pm 8.3$ & $65.4 \pm 20.9 b$ & $58.9 \pm 25.7$ & $2.4 \pm 0.4 b$ \\
\hline 20.0 & 30 & $28.9 \pm 9.0 \mathrm{c}$ & $31.4 \pm 12.5$ & 100.0 & 30 & $1.8 \pm 0.4 \mathrm{ef}$ & $21.7 \pm 5.9 \mathrm{~b}$ & $26.4 \pm 5.2$ & $78.3 \pm 14.6 \mathrm{a}$ & $78.9 \pm 19.4$ & $3.8 \pm 0.6 \mathrm{a}$ \\
\hline 25.0 & 30 & $14.2 \pm 7.1 \mathrm{~d}$ & $28.2 \pm 4.3$ & 100.0 & 30 & $1.3 \pm 0.5 \mathrm{f}$ & $12.4 \pm 6.3 \mathrm{c}$ & $23.8 \pm 3.6$ & $42.5 \pm 18.8 \mathrm{c}$ & $83.0 \pm 21.5$ & $3.6 \pm 0.7 a$ \\
\hline 27.5 & 30 & $11.5 \pm 6.0 \mathrm{~d}$ & & 93.3 & 28 & $2.5 \pm 0.6 \mathrm{e}$ & $7.3 \pm 3.6 \mathrm{~cd}$ & & $16.9 \pm 9.3 \mathrm{de}$ & & $2.3 \pm 0.8 b$ \\
\hline $30.0^{2}$ & 30 & $3.7 \pm 1.3 \mathrm{~d}$ & $13.3 \pm 5.7$ & 80.0 & 24 & $1.5 \pm 0.6 \mathrm{f}$ & $2.6 \pm 1.2 \mathrm{~d}$ & $11.2 \pm 6.1$ & $4.4 \pm 2.3 \mathrm{f}$ & $25.4 \pm 14.8$ & $1.7 \pm 0.5 \mathrm{c}$ \\
\hline 35.0 & & & $4.2 \pm 2.1$ & & & & & $2.3 \pm 1.8$ & & $2.5 \pm 1.7$ & \\
\hline
\end{tabular}

${ }^{1}$ Initial number means the number of adults that emerged from nymphal stage. ${ }^{2}$ The adults at $30^{\circ} \mathrm{C}$ were treated separately without examination of their nymphal stages. ${ }^{3}$ Reproductive rate was calculated as the percentage of the initial number of adults that produced progeny. ${ }^{4}$ These data are from soybean in Kim et al. [2], in which 20 adults were replicated and Paldalkong cultivar was used. ${ }^{5}$ Different letters within a column indicate statistically significant difference among means by Tukey's HSD test at $\alpha=0.05$. ANOVA results were $F_{8,250}=$ $58.09(p<0.0001)$ for longevity, $F_{8,236}=677.57(p<0.0001)$ for pre-reproductive period, $F_{8,236}=57.93(p<0.0001)$ for reproductive period, $F_{8,236}=128.48(p<0.0001)$ for total fecundity, and $F_{8,236}=158.57(p<0.0001)$ for daily fecundity during reproductive period. 


\subsection{Estimation of Developmental and Reproductive Patterns Based on Models}

LDT and the degree-days (DD) above LDT required to complete nymphal development (i.e., the thermal constant) were determined to be $5.02{ }^{\circ} \mathrm{C}$ and $131.2 \mathrm{DD}$, respectively, based on the linear development model (Equation (1)) (Table 3 and Figure 1). The LDTs of each separate nymphal instar estimated using the linear model ranged from 5.39 to $6.32^{\circ} \mathrm{C}$ (Table 4 ). The LDT of the nymphal stage overall determined using the Lactin-2 model (Equation (2)) was $-1.85^{\circ} \mathrm{C}$ (Table 3 ). The estimated upper lethal temperature (UDT) was 33.9 C. The optimal temperature was estimated to be $26.87^{\circ} \mathrm{C}$. The two development rate models had very high adjusted coefficients of determination $\left(r_{\text {adj }}{ }^{2}\right)$ values, which were $\geq 0.99$ for both models. The data for inter-individual variation in developmental completion were fit well by the model tested (Equation (3)), with a high $r_{\text {adj }}{ }^{2}$ value of 0.90 (Table 3 and Figure 1). The model parameters and values derived from this model for each nymphal instar are provided in Table 4.

Table 3. Parameters and values derived from the development rate models and the distribution model for A. solani nymphs in Figure 1.

\begin{tabular}{ccc}
\hline Model & Parameters and Derived Estimates & radj $^{2}$ \\
\hline $\begin{array}{c}\text { Developmental rate Linear } \\
\text { (Equation (1)) }\end{array}$ & $\begin{array}{c}a=0.00762 \pm 0.00026, b=-0.03824 \pm 0.00420 \text { (Temperature } \\
\text { range 7.5 25 }{ }^{\circ} \mathrm{C} \text { ), LDT }=5.02, \mathrm{DD}=131.19\end{array}$ & 0.99 \\
\hline & $P=0.14202 \pm 0.01970, T_{\mathrm{L}}(\mathrm{UDT})=33.88565 \pm 1.61807, \Delta T$ & \\
Lactin-2 (Equation (2)) & $=7.01425 \pm 0.95905, \lambda=-0.01491 \pm 0.01322, \mathrm{LDT}=-1.85$, & 0.99 \\
& $T_{\text {opt }}=26.87$ & 0.90 \\
\hline Weibull distribution (Equation (3)) & $\eta=0.99247 \pm 0.00444, \beta=17.94321 \pm 1.87829$ & \\
\hline
\end{tabular}

ANOVA results were $F_{1,4}=857.0(p<0.0001)$ for the linear model, $F_{3,4}=448.7(p<0.0001)$ for the Lactin-2 model, and $F_{1,40}=365.0(p<0.0001)$ for the Weibull distribution model. Abbreviations: LDT, lower development threshold; $\mathrm{DD}$, degree-days; UDT, upper development threshold; $r_{\text {adj }}{ }^{2}$, adjusted $r$ square value.
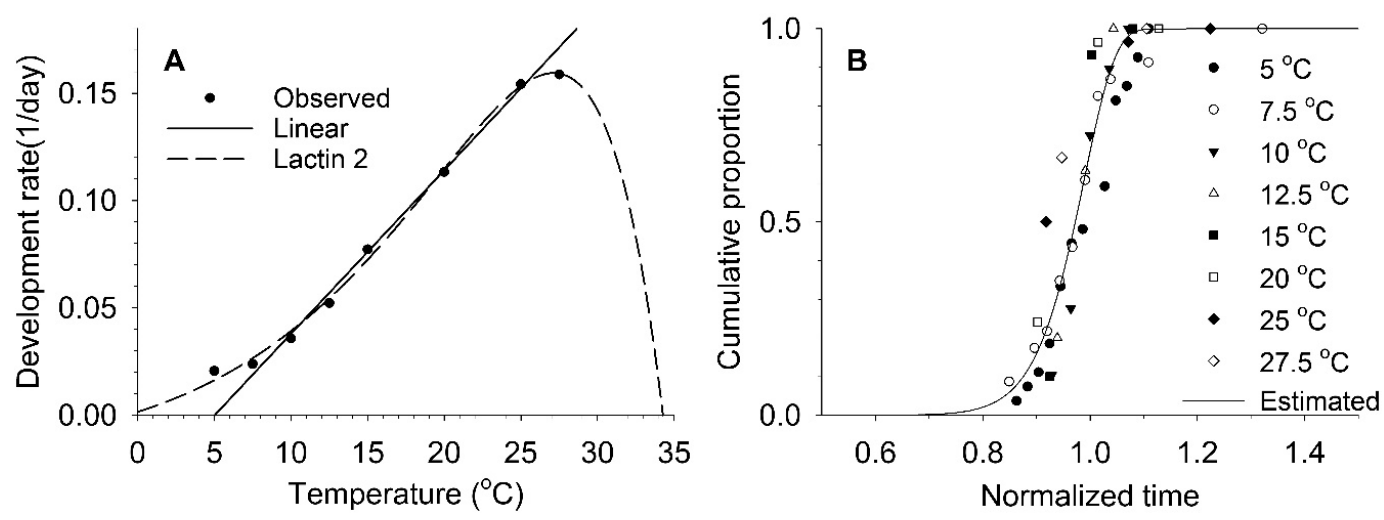

Figure 1. Observed values of development rates at constant temperatures and estimated linear (Equation (1)) and nonlinear Lactin-2 model (Equation (2)) curves between temperature and development rates (A), and Weibull distribution curve (Equation (3)) for development completion (B) in A. solani nymphs.

Aging rate increased exponentially with increasing temperature, and its generalized model (Equation (4)) achieved a high $r_{\mathrm{adj}}{ }^{2}$ value of 0.88 (Table 5 and Figure 3). However, the model underestimated observed aging rates between 5 and $20^{\circ} \mathrm{C}$. The total fecundity model (Equation (5)) achieved an $r_{\text {adj }}{ }^{2}$ value of 0.74 , and estimated that the maximum fecundity of this species on soybean is ca. 76.9 nymphs per adult at an optimum temperature of $18.1^{\circ} \mathrm{C}$. Survival (Equation (6)) and cumulative fecundity (Equation (3)) models applied to the normalized ages of adults fit the observed values well, with high $r_{\text {adj }}{ }^{2}$ values. 
Table 4. Parameters and values derived from the linear and nonlinear temperature-dependent development models in separate instars of $A$. solani nymphs.

\begin{tabular}{|c|c|c|c|c|c|}
\hline Model & $\begin{array}{c}\text { Parameters and Derived } \\
\text { Values }\end{array}$ & First Instar & Second Instar & Third Instar & Fourth Instar \\
\hline \multirow[t]{6}{*}{ Linear } & $a$ (slope) & $0.03351 \pm 0.00093$ & $0.03579 \pm 0.00151$ & $0.04072 \pm 0.00336$ & $0.0298 \pm 0.00178$ \\
\hline & $b$ (intercept) & $-0.18052 \pm 0.01608$ & $-0.20268 \pm 0.02740$ & $-0.25756 \pm 0.05424$ & $-0.1702 \pm 0.02871$ \\
\hline & Temp. range $\left({ }^{\circ} \mathrm{C}\right)$ & $10.0-25.0$ & $7.5-27.5$ & $7.5-25.0$ & $7.5-25.0$ \\
\hline & LDT and DD & $5.39,29.8$ & $5.66,27.9$ & $6.32,24.6$ & $5.70,33.5$ \\
\hline & $r_{\text {adj. }}^{2}$ & 1.00 & 0.99 & 0.96 & 0.98 \\
\hline & ANOVA & $\begin{array}{c}F_{1,3}=1308.8 \\
(p<0.0001)\end{array}$ & $\begin{array}{l}F_{1,5}=565.0 \\
(p<0.0001)\end{array}$ & $\begin{array}{l}F_{1,4}=146.8 \\
(p=0.0003)\end{array}$ & $\begin{array}{l}F_{1,4}=281.1 \\
(p<0.0001)\end{array}$ \\
\hline \multirow{8}{*}{ Lactin-2 } & $P$ & $0.14597 \pm 0.01197$ & $0.18764 \pm 0.02063$ & $0.23443 \pm 0.01455$ & $0.19659 \pm 0.02063$ \\
\hline & $T_{\mathrm{L}}(\mathrm{UDT})$ & $33.78729 \pm 0.60461$ & $32.08891 \pm 0.51063$ & $30.30548 \pm 0.11484$ & $30.34261 \pm 0.60381$ \\
\hline & $\Delta T$ & $6.75625 \pm 0.52066$ & $5.30357 \pm 0.56751$ & $4.25799 \pm 0.26086$ & $5.06637 \pm 0.52048$ \\
\hline & $\lambda$ & $-0.024430 \pm 0.03485$ & $0.02808 \pm 0.04283$ & $0.06220 \pm 0.03000$ & $0.01504 \pm 0.03185$ \\
\hline & LDT & -8.36 & -1 & -1 & -1 \\
\hline & $T_{\text {opt }}$ & 27.03 & 26.79 & 26.05 & 25.28 \\
\hline & $r_{\text {adj. }}{ }^{2}$ & 0.99 & 0.97 & 0.98 & 0.99 \\
\hline & ANOVA & $\begin{array}{l}F_{3,6}=409.1 \\
(p<0.0001)\end{array}$ & $\begin{array}{l}F_{3,6}=121.3 \\
(p<0.0001)\end{array}$ & $\begin{array}{l}F_{3,5}=188.2 \\
(p<0.0001)\end{array}$ & $\begin{array}{l}F_{3,4}=214.2 \\
(p<0.0001)\end{array}$ \\
\hline Weibull & $\eta$ & $0.96899 \pm 0.01653$ & $0.94956 \pm 0.01867$ & $0.91102 \pm 0.02093$ & $0.96280 \pm 0.00995$ \\
\hline \multirow[t]{3}{*}{ distribution } & $\beta$ & $3.91272 \pm 0.38530$ & $7.50896 \pm 1.75786$ & $5.59675 \pm 1.07504$ & $10.54906 \pm 1.46181$ \\
\hline & $r_{\text {adj. }}{ }^{2}$ & 0.89 & 0.73 & 0.78 & 0.90 \\
\hline & ANOVA & $\begin{array}{c}F_{1,43}=363.5 \\
(p<0.0001)\end{array}$ & $\begin{array}{l}F_{1,30}=90.3 \\
(p<0.0001)\end{array}$ & $\begin{array}{c}F_{1,28}=111.4 \\
(p<0.0001)\end{array}$ & $\begin{array}{c}F_{1,27}=273.5 \\
(p<0.0001)\end{array}$ \\
\hline
\end{tabular}

${ }^{1}$ The parameters could not be calculated. Abbreviation: $T_{\mathrm{opt}}$, optimal temperature. 

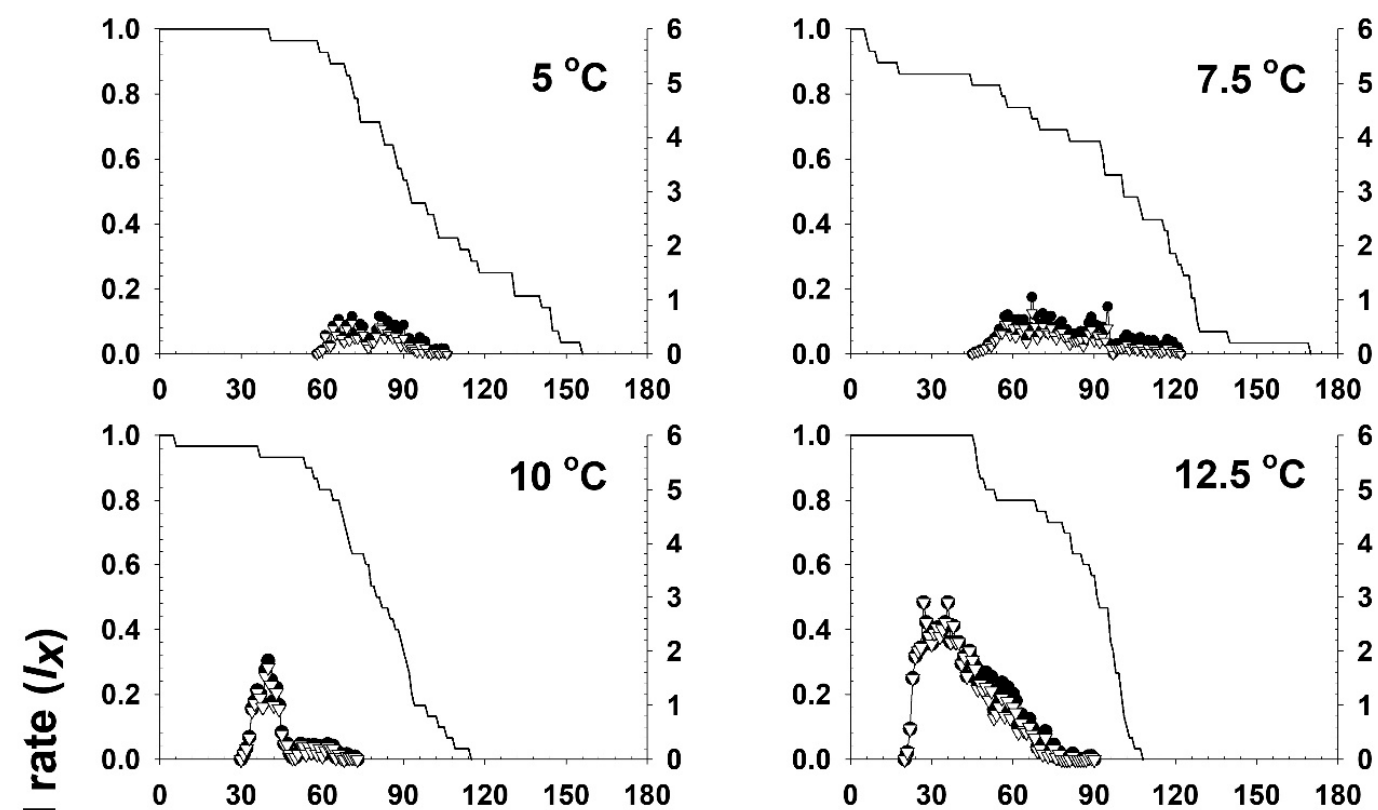

$\frac{x}{2}$
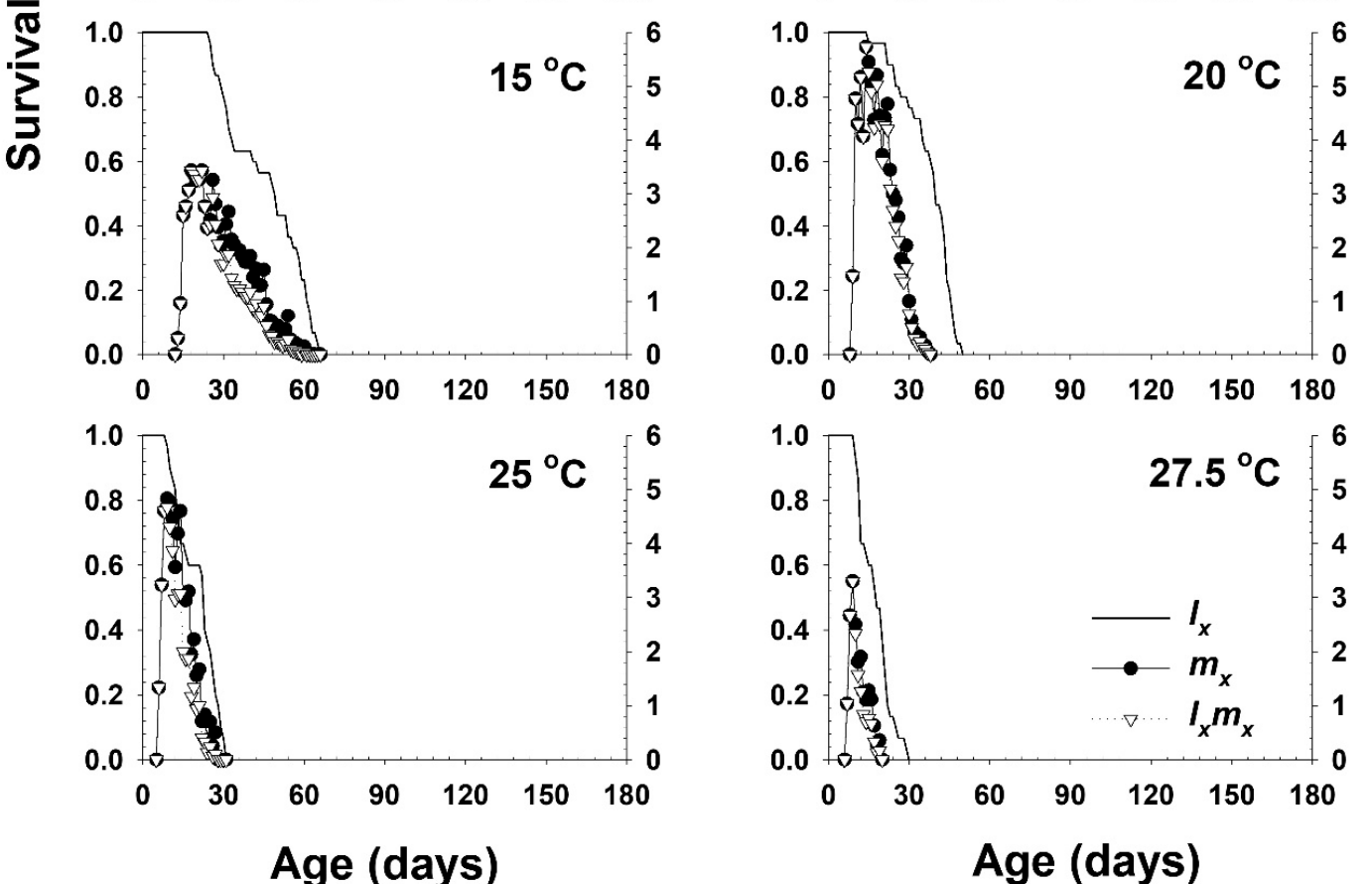

Figure 2. The age-specific survival rate $\left(l_{x}\right)$, the age-specific fecundity $\left(m_{x}\right)$, and the age-specific maternity $\left(l_{x} m_{x}\right)$ of $A$. solani in response to different temperature conditions.

Table 5. Several models and their parameters for $A$. solani adults in Figure 2.

\begin{tabular}{ccc}
\hline Model & Parameters & $\boldsymbol{r}_{\mathrm{adj}^{2}}$ \\
\hline Aging rate (Equation (4)) & $a=4.70782 \pm 7.95564, b=183.66418 \pm 49.24300$ & 0.88 \\
\hline Total fecundity (Equation (5)) & $a=0.0074 \pm 0.0182, T_{L}=3.4950 \pm 3.0050, T_{M}=30.0000 \pm$ & 0.74 \\
\hline Survival ratio (Equation (6)) & $3.7360, m=0.6756 \pm 0.3867$ & 0.92 \\
\hline $\begin{array}{c}\text { Cumulative fecundity ratio } \\
\text { (Equation (3)) }\end{array}$ & $\eta=0.97594 \pm 0.00988, \delta=-0.27363 \pm 0.01034$ & 0.91 \\
\hline
\end{tabular}

ANOVA results were $F_{1,7}=70.96(p<0.0001)$ for aging rate, $F_{3,5}=11.17(p=0.0177)$ for total fecundity, $F_{1,174}=1949.19$ $(p<0.0001)$ for survival ratio, and $F_{1,566}=5751.26(p<0.0001)$ for cumulative fecundity ratio. 

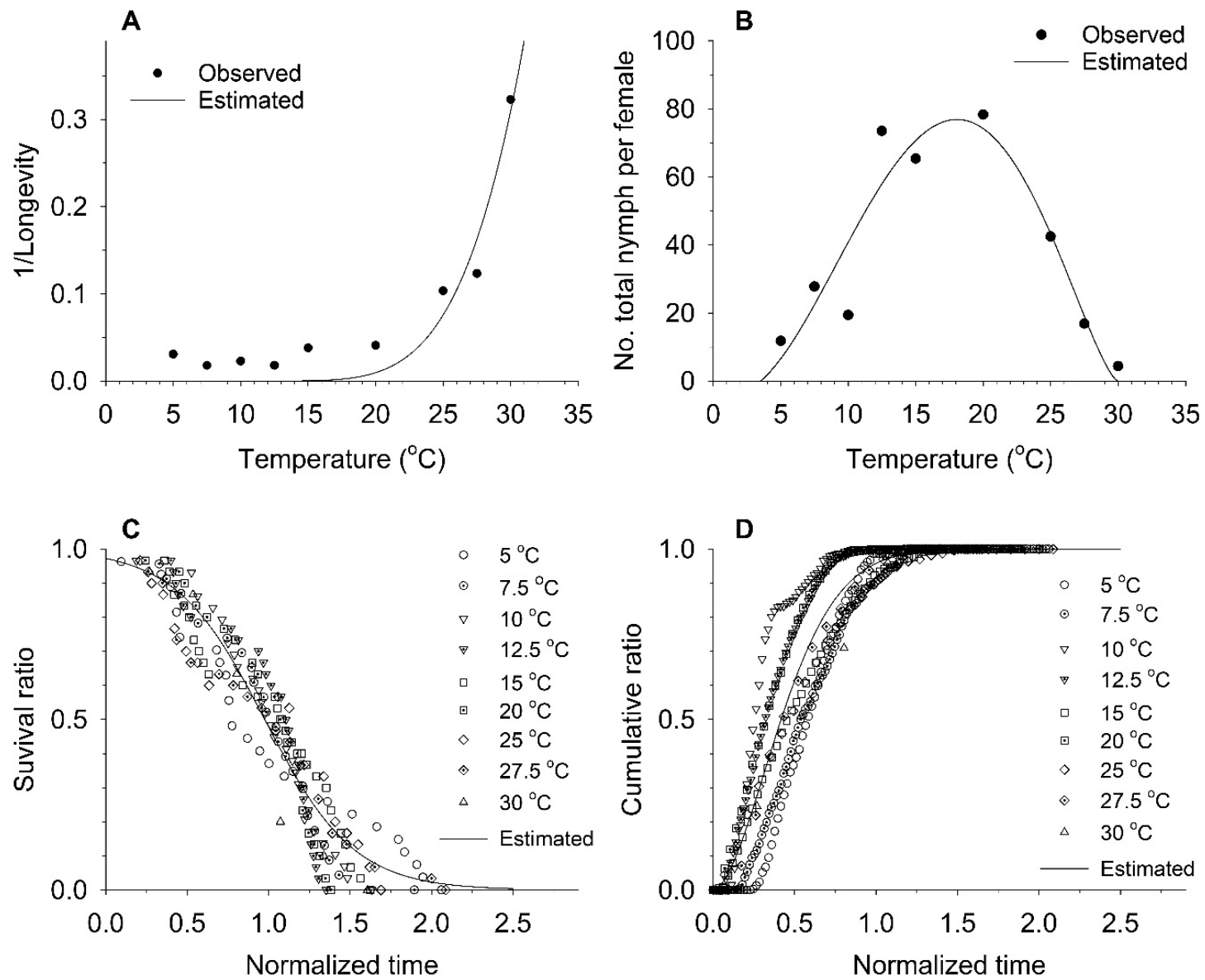

Figure 3. Observed values of the aging rate (A), total fecundity (B), cumulative survival ratio (C), and cumulative fecundity ratio (D), and curves estimated from their generalized models (Equation (4), Equation (5), Equation (6), Equation (3)) in A. solani adults.

The age-dependent daily mortality of adults at particular temperatures rapidly decreased with increasing temperature. The age-specific survival rate and fecundity of $A$. solani are presented in Figure 2. The age-specific survival rate $\left(l_{x}\right)$ is the sum of $s_{x j}$ at each age $x$ and is the simplified version of $s_{x j}$. The curves sharply dropped at an earlier age from $15^{\circ} \mathrm{C}$ to $27.5{ }^{\circ} \mathrm{C}$. The daily fecundity at temperatures from 10 to $27.5^{\circ} \mathrm{C}$ sharply increased at earlier ages, and slowly decreased thereafter until the final parthenogenesis occurred, while at lower temperatures of 5 and $7.5^{\circ} \mathrm{C}$, daily fecundity values were relatively stable across ages. The highest age-specific fecundities were $0.70(81 \mathrm{~d}), 1.04(67 \mathrm{~d})$, $1.82(40 \mathrm{~d}), 2.90$ (36 d), $3.43(22 \mathrm{~d}), 5.73$ (14 d), $4.82(9 \mathrm{~d})$, and $3.30(9 \mathrm{~d})$ offspring at 5, 7.5, 10, 12.5, 15, 20, 25 , and $27.5^{\circ} \mathrm{C}$, respectively. The peaks of $m_{x}$ and $l_{x} m_{x}$ tended to increase with increasing temperature from $5{ }^{\circ} \mathrm{C}$ to $20^{\circ} \mathrm{C}$. The model (Equation (7)) used to generalize the relationship between adult age and daily fecundity fit the observed data well at temperatures between 12.5 and $25^{\circ} \mathrm{C}$, with a high $r_{\text {adj }}{ }^{2}$ value over 0.9 . The performance of this model at lower $\left(5 \sim 10^{\circ} \mathrm{C}\right)$ and higher temperatures $(27.5$ and $30{ }^{\circ} \mathrm{C}$ ) than those in this range, however, was relatively poor (Table 6). The model estimated the highest fecundity to be ca. 88.5 nymphs per adult at $20^{\circ} \mathrm{C}$. However, the estimated pre-reproductive periods $\left(p_{2}\right)$ in the model were shorter than the observed periods at all temperatures. Although the $p_{2}$ parameter of the model at $25{ }^{\circ} \mathrm{C}$ gave a negative value, it was close to zero. The maximum daily fecundity was estimated to be ca. 6.1 nymphs per adult for a 5.2 day old of adult at $21.3^{\circ} \mathrm{C}$ in the ageand temperature-dependent daily fecundity model (Equation (8)) (Table 7). 
Table 6. Parameters estimated from the daily fecundity model (Equation (7)) of A. solani adults at constant temperatures.

\begin{tabular}{ccccc}
\hline Temp $\left({ }^{\circ} \mathbf{C}\right)$ & $p_{1}$ & $p_{\mathbf{2}}$ & $p_{\mathbf{3}}$ & $\boldsymbol{r}_{\text {adj. }}{ }^{2}$ \\
\hline 5.0 & $18.12654 \pm 1.31138$ & $3.98639 \pm 0.68477$ & $0.05573 \pm 0.00382$ & 0.58 \\
7.5 & $31.87245 \pm 1.52136$ & $3.74750 \pm 0.60615$ & $0.04654 \pm 0.00221$ & 0.70 \\
10.0 & $22.88171 \pm 1.72476$ & $1.52812 \pm 0.33140$ & $0.12175 \pm 0.00871$ & 0.66 \\
12.5 & $83.24260 \pm 1.99011$ & $1.21637 \pm 0.20426$ & $0.08076 \pm 0.00201$ & 0.93 \\
15.0 & $83.47867 \pm 2.64907$ & $0.22761 \pm 0.24133$ & $0.10680 \pm 0.00374$ & 0.91 \\
20.0 & $88.53896 \pm 3.64552$ & $0.18145 \pm 0.17975$ & $0.17008 \pm 0.00750$ & 0.91 \\
25.0 & $57.06038 \pm 2.09382$ & $-0.04473 \pm 0.12002$ & $0.23537 \pm 0.00946$ & 0.94 \\
27.5 & $22.04102 \pm 1.87325$ & $0.30660 \pm 0.15650$ & $0.30116 \pm 0.02514$ & 0.81 \\
30.0 & $4.90767 \pm 0.85356$ & $0.00785 \pm 0.13275$ & $0.64841 \pm 0.12095$ & 0.61 \\
\hline
\end{tabular}

ANOVA results were $F_{2,107}=76.82(p<0.0001)$ for $5^{\circ} \mathrm{C}, F_{2,125}=148.62(p<0.0001)$ for $7.5^{\circ} \mathrm{C}, F_{2,85}=88.41(p<0.0001)$ for $10{ }^{\circ} \mathrm{C}, F_{2,86}=627.95(p<0.0001)$ for $12.5^{\circ} \mathrm{C}, F_{2,52}=263.86(p<0.0001)$ for $15^{\circ} \mathrm{C}, F_{2,38}=208.32(p<0.0001)$ for $20^{\circ} \mathrm{C}$, $F_{2,22}=197.73(p<0.0001)$ for $25^{\circ} \mathrm{C}, F_{2,22}=56.01(p<0.0001)$ for $27.5^{\circ} \mathrm{C}$, and $F_{2,4}=8.32(p=0.0375)$ for $30^{\circ} \mathrm{C}$.

Table 7. Parameters estimated from the age- and temperature-dependent daily fecundity model (Equation (8)) of A. solani adults.

\begin{tabular}{cc}
\hline Parameter Estimates & $\boldsymbol{r}_{\text {adj. }}{ }^{2}$ \\
\hline$\varepsilon=-3.42273 \pm 0.11850, \theta=0.02574 \pm 0.00096, \kappa=$ \\
$-0.00074 \pm 0.00003, \rho=-3.15503 \pm 0.06940, v=$ \\
$0.00574 \pm 0.00057, \psi=-0.00012 \pm 0.00002$ & 0.90 \\
\hline \multicolumn{2}{c}{ ANOVA result is $F_{5,562}=981.4(p<0.0001)}$.
\end{tabular}

\subsection{Life Table}

The intrinsic rate of increase $\left(r_{\mathrm{m}}\right)$ and the finite rate of increase $(\lambda)$ from both analyses were highest at $25^{\circ} \mathrm{C}\left(0.3349,0.3377\right.$, and 1.40 , respectively). Doubling time (DT) was shortest at $25{ }^{\circ} \mathrm{C}$ (2.07 and 2.05 days). Net reproductive rate $\left(R_{0}\right)$ was highest at $20^{\circ} \mathrm{C}$ (77.49 and 78.34 nymphs), and the temperature with the second-highest $R_{0}$ value was $12.5^{\circ} \mathrm{C}$ (73.19 and 73.56 nymphs) (Tables 8 and 9). The generation time $(\mathrm{G})$ decreased with increasing temperature.

Table 8. Life table parameters of $A$. solani at different constant temperatures using traditional age-specific life table analysis.

\begin{tabular}{cccccc}
\hline Temp. $\left({ }^{\circ} \mathbf{C}\right)$ & $\boldsymbol{r}_{\mathbf{m}}$ & $\boldsymbol{R}_{\mathbf{0}}$ (No.) & G (Day) & $\boldsymbol{\lambda}$ & DT (Day) \\
\hline 5.0 & 0.0297 & 9.61 & 76.29 & 1.03 & 23.37 \\
7.5 & 0.0405 & 18.51 & 72.08 & 1.04 & 17.12 \\
10.0 & 0.0699 & 18.71 & 41.91 & 1.07 & 9.92 \\
12.5 & 0.1226 & 73.19 & 35.02 & 1.13 & 5.65 \\
15.0 & 0.1813 & 64.21 & 22.95 & 1.20 & 3.82 \\
20.0 & 0.2774 & 77.49 & 15.68 & 1.32 & 2.50 \\
25.0 & 0.3349 & 40.67 & 11.06 & 1.40 & 2.07 \\
27.5 & 0.2489 & 14.79 & 10.82 & 1.28 & 2.79 \\
\hline
\end{tabular}

$r_{\mathrm{m}}$ : intrinsic rate of increase, $R_{0}$ : net reproductive rate in numbers, G: generation time in days, $\lambda$ : finite rate of increase, and DT: doubling time of population in days.

The population growth and stage structure at different temperatures based on the age-stage, two-sex life table is presented in Figure 4. The populations from $20{ }^{\circ} \mathrm{C}$ and $25^{\circ} \mathrm{C}$ increased significantly faster than those at lower temperature conditions. 

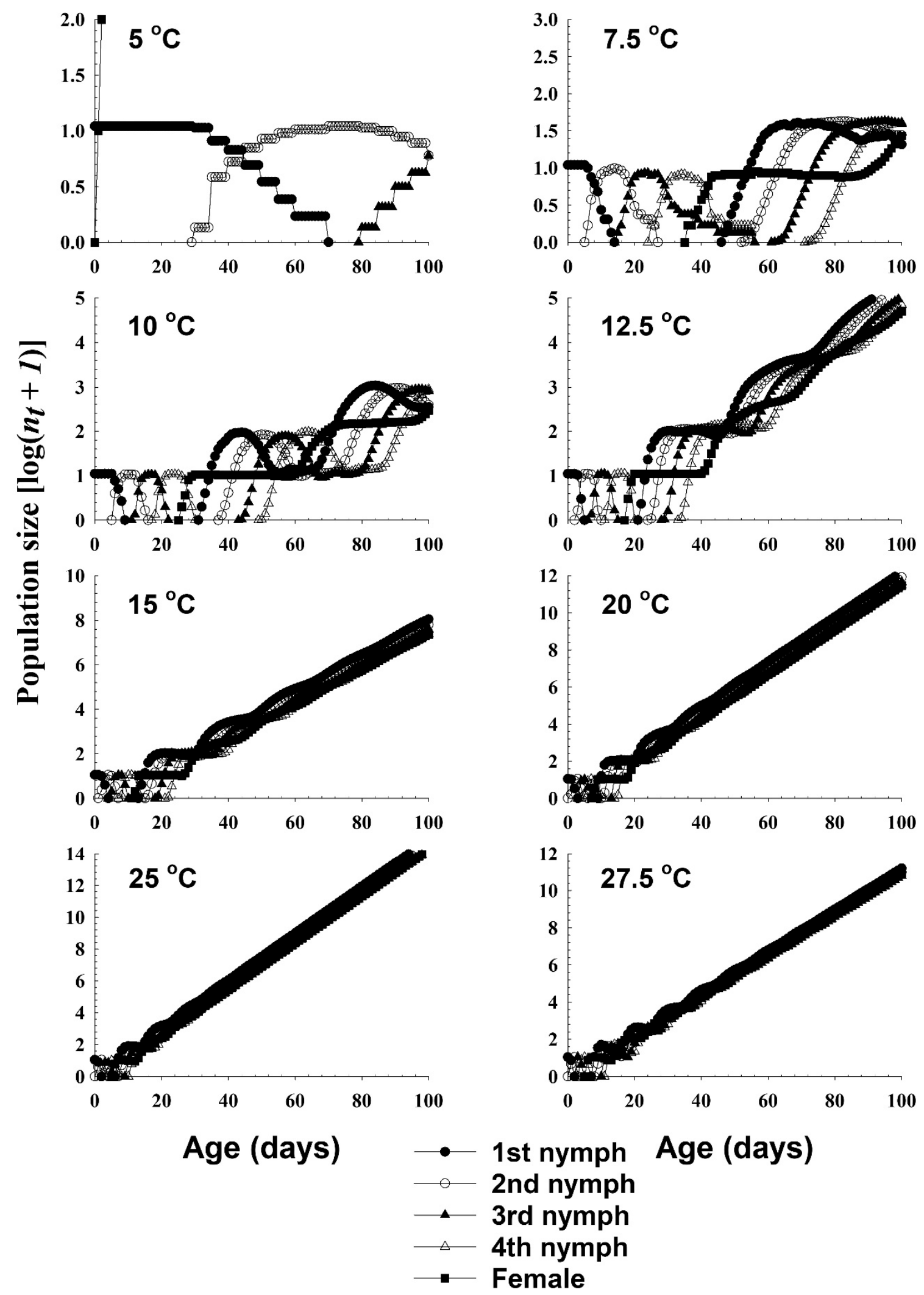

Figure 4. The population growth projection of $A$. solani in response to different temperature conditions, beginning with an initial population of newly born 10 nymphs. 
Table 9. Life table parameters of $A$. solani at different constant temperatures using age-stage, two-sex life table analysis.

\begin{tabular}{cccccc}
\hline Temp. $\left({ }^{\circ} \mathbf{C}\right)$ & $\boldsymbol{r}_{\mathbf{m}}$ & $\boldsymbol{R}_{\mathbf{0}}$ (No.) & G (Day) & $\boldsymbol{\lambda}$ & DT (Day) \\
\hline 5.0 & $0.0307 \mathrm{~h}$ & $10.51 \mathrm{e}$ & $76.36 \mathrm{a}$ & $1.03 \mathrm{~h}$ & $22.61 \mathrm{a}$ \\
7.5 & $0.0402 \mathrm{~g}$ & $18.17 \mathrm{~d}$ & $71.85 \mathrm{~b}$ & $1.04 \mathrm{~g}$ & $17.32 \mathrm{~b}$ \\
10.0 & $0.0689 \mathrm{f}$ & $17.68 \mathrm{~d}$ & $41.66 \mathrm{c}$ & $1.07 \mathrm{f}$ & $10.06 \mathrm{c}$ \\
12.5 & $0.1226 \mathrm{e}$ & $73.56 \mathrm{ab}$ & $35.05 \mathrm{~d}$ & $1.13 \mathrm{e}$ & $5.65 \mathrm{~d}$ \\
15.0 & $0.1827 \mathrm{~d}$ & $65.29 \mathrm{~b}$ & $22.86 \mathrm{e}$ & $1.20 \mathrm{~d}$ & $3.79 \mathrm{e}$ \\
20.0 & $0.2774 \mathrm{~b}$ & $78.34 \mathrm{a}$ & $15.72 \mathrm{f}$ & $1.32 \mathrm{~b}$ & $2.50 \mathrm{~g}$ \\
25.0 & $0.3377 \mathrm{a}$ & $42.52 \mathrm{c}$ & $11.09 \mathrm{~g}$ & $1.40 \mathrm{a}$ & $2.05 \mathrm{~h}$ \\
27.5 & $0.2534 \mathrm{c}$ & $15.79 \mathrm{~d}$ & $10.87 \mathrm{~g}$ & $1.28 \mathrm{c}$ & $2.74 \mathrm{f}$ \\
\hline
\end{tabular}

$r_{\mathrm{m}}$ : intrinsic rate of increase, $R_{0}$ : net reproductive rate in numbers, G: generation time in days, $\lambda$ : finite rate of increase, and DT: doubling time of population in days. Means in the same row followed by different letters are significantly different $(p<0.05)$, as determined by the paired bootstrap test.

\section{Discussion}

The development of insects can be affected by the nutritional value of their host plant, as well as by temperature. The duration of the nymphal period of $A$. solani on different host plants, including eggplant (Solanum melongena L. (Solanales: Solanaceae)), fennel (Foeniculum vulgare Mill (Apiales: Apiaceae)), lettuce, pea (Pisum sativum L. (Fabales: Fabaceae)), pansy, potato (Solanum tuberosum L. (Solanales: Solanaceae)), and soybean, are as follows: 48.7-63.15 days at $5{ }^{\circ} \mathrm{C}, 16.7-28.0$ days at $10{ }^{\circ} \mathrm{C}, 16.9-19.2$ days at $12.5^{\circ} \mathrm{C}, 10.3-13.4$ days at $15^{\circ} \mathrm{C}, 7.2-8.9$ days at $20^{\circ} \mathrm{C}, 6.5-7.4$ days at $25^{\circ} \mathrm{C}$, 6.3 days at $27.5^{\circ} \mathrm{C}$ (data from this study and Jandricic et al. [20]). The nymphal period of A. solani on the same plant species, soybean, as that used in our study was previously observed to be ca. 20 days at $10{ }^{\circ} \mathrm{C}$ by Kim et al. [2], which differed considerably from our result (28 days) at this temperature; however, the results of our study and theirs at other common temperatures were not so different (Table 1). The difference of development time at $10{ }^{\circ} \mathrm{C}$ may have been due to the use of different cultivars (Taegwangkong and Paldalkong) in the two studies.

The lowest experimental temperature tested in this study was $2.5^{\circ} \mathrm{C}$, which caused $100 \%$ mortality of A. solani nymphs on soybean (Table 1). Similarly, Pozarowska [41] reported no survival of nymphs of this species kept at $2{ }^{\circ} \mathrm{C}$ on potato. LDTs estimated for this species with the linear model were $5.02{ }^{\circ} \mathrm{C}$ on soybean in this study (Table 3), $4.8^{\circ} \mathrm{C}$ on lettuce [19], and $3.69^{\circ} \mathrm{C}$ on pansy [20]. LDTs estimated using the linear model are usually different depending on the temperature range used, even within the same experiment, and thus the thermal constants for the completion of development estimated also vary along with these different LDTs. Other estimated LDTs on lettuce were $1.09^{\circ} \mathrm{C}$ and $0.08{ }^{\circ} \mathrm{C}[16,17]$. Generally, the LDTs for aphid species are lower than those for members of other insect orders. Indeed, based on data published in the literature for 28 cases from 16 species of aphids, the mean \pm SD values of LDT and DD for the completion of development estimated from the linear model were $4.1 \pm 1.6^{\circ} \mathrm{C}$ and $131.4 \pm 38.3 \mathrm{DD}$, respectively [10]. These values cover all of the LDTs and DDs estimated for the nymphal stages of $A$. solani in this study (Tables 1 and 4). The Lactin-2 model estimated the LDT to be $-1.85^{\circ} \mathrm{C}$ in this study (Table 3), but this value is probably not realistic because we observed that all nymphs died at the much higher temperature of $2.5^{\circ} \mathrm{C}$. The LDT of this species on pansy was previously estimated with the Lactin- 2 model to be $4.0^{\circ} \mathrm{C}$ [20], which is more realistic. The low LDTs estimated for $A$. solani indicate that this aphid is adapted to lower temperatures, and as a result of this, its survival rates during the winter in temperate regions should be relatively high. Indeed, the survival of anholocyclic forms of A. solani on weeds over the winter season in Scotland was previously reported [9].

Generally, the development of insects is retarded at temperatures above their optimal temperature. In this study, the nymphal period was not retarded by increasing temperature between 5 and $27.5^{\circ} \mathrm{C}$, and survival was high at all these temperatures. However, the developmental periods of the first, second, and third nymphal instars at $30^{\circ} \mathrm{C}$ were longer than those at $27.5^{\circ} \mathrm{C}$. The duration of the 
fourth instar at $27.5^{\circ} \mathrm{C}$ was also longer than that at $25^{\circ} \mathrm{C}$, although this difference was not statistically significant (Table 1). This property was also observed in other studies of $A$. solani, in which longer nymphal periods occurred at $25^{\circ} \mathrm{C}$ than $22.5^{\circ} \mathrm{C}$ on lettuce [17], at $28^{\circ} \mathrm{C}$ than $25^{\circ} \mathrm{C}$ on lettuce [16], and at $30^{\circ} \mathrm{C}$ than $25^{\circ} \mathrm{C}$ on pansy [20].

At the highest temperature tested in this study, $30^{\circ} \mathrm{C}$, mortality during the nymphal period was $100 \%$, which agreed with the results of two previous studies also conducted on soybean [2,42]. Data for nymphs raised on other host plants are also similar, as $100 \%$ mortality was reported to occur at $31^{\circ} \mathrm{C}$ on lettuce [16] and high mortality, ca. $88 \%$, at $30{ }^{\circ} \mathrm{C}$ and $100 \%$ mortality at $35{ }^{\circ} \mathrm{C}$ was reported on pansy [20]. However, a study on lettuce produced a different result, in that ca. $97 \%$ mortality occurred at $27.5^{\circ} \mathrm{C}$ [17]. The Lactin-2 model estimated the value of this species' upper developmental threshold to be $33.9{ }^{\circ} \mathrm{C}$, which was higher than the range of temperatures observed in this study (Tables 1 and 3). For nymphs reared on pansy, this parameter was estimated to be $37.6^{\circ} \mathrm{C}$ based on the Lactin-2 model, and this value was also higher than the observed temperatures at which high or total mortality occurred [20].

The optimal temperature estimated using the Lactin-2 model for the nymphal development of A. solani on soybean was $26.87^{\circ} \mathrm{C}$ in this study, while the optimal temperature for nymphs reared on pansy was previously estimated to be $25.7^{\circ} \mathrm{C}$ based on the Lactin- 2 model [20].

The range of temperatures $\left(12.5-20^{\circ} \mathrm{C}\right)$ over which we found higher fecundities was similar to that found in other studies, which was $16-22{ }^{\circ} \mathrm{C}$ and $12.5-20^{\circ} \mathrm{C}$ on lettuce, and $10-20{ }^{\circ} \mathrm{C}$ on pansy $[15,17,20]$. The maximum total fecundities of $A$. solani estimated were commonly below 90 nymphs per adult in all previous studies, which agrees with our results. However, it appears that high temperatures above $20^{\circ} \mathrm{C}$ can suppress the reproduction of $A$. solani, since we observed that the total fecundity and net reproductive rate $\left(R_{0}\right)$ decreased significantly at $25^{\circ} \mathrm{C}$ compared to at $20^{\circ} \mathrm{C}$, at which the highest fecundity and $R_{0}$ values were found (Tables 2 and 6). Similar results were found in other studies, wherein total fecundity and $R_{0}$ on lettuce were ca. 68 and 63 nymphs per adult, respectively, at $22^{\circ} \mathrm{C}$, but ca. 18 and 23 nymphs at $25^{\circ} \mathrm{C}$ [15]; on pansy, these were ca. 68 and ca. 64 nymphs at $20{ }^{\circ} \mathrm{C}$, but ca. 39 and ca. 37 nymphs at $25^{\circ} \mathrm{C}$ [20]. However, these findings should be further confirmed, because Kim et al. [2]'s study rearing this species on soybean showed that the highest fecundity, ca. 83 nymphs per adult, occurred at $25^{\circ} \mathrm{C}$.

Several characteristics of the adult biology of $A$. solani on soybean in the study described in Kim et al. [2] were quite different from the results of this study. Adult longevities and reproductive periods at $25^{\circ} \mathrm{C}$ and $30^{\circ} \mathrm{C}$ were much longer in Kim et al. [2] than those in this study. Total fecundities at 10 and $30^{\circ} \mathrm{C}$ were also much higher in the previous study [2]. Fecundity is an ideal biological trait for demonstrating the quality of a particular host by measuring the reproductive success of the species. It may be inferred that the differences were caused by the use of different soybean cultivars, and aphid incubation methods, experimental conditions, and differences in the local populations of the aphid in the two studies. Montllor et al. [43] found that when Acythosiphon pisum had been heat-stressed for a period of about $4 \mathrm{~h}$ at $39^{\circ} \mathrm{C}$ as young ( 1 day) or as older ( 5 day) nymphs, A. pisum without pea aphid secondary symbiont (PASS) or pea aphid rickettsia (PAR) failed to reproduce, though not necessarily to survive. Although we did not identify the facultative bacterial secondary symbionts of $A$. solani in this study, it may be speculated there is a relationship between development and the facultative symbionts of $A$. solani, because the species could not develop the adult stage at $30{ }^{\circ} \mathrm{C}$ and $35{ }^{\circ} \mathrm{C}$ but they reproduced at the same temperature.

Life table parameters (the intrinsic rate of increase, finite rate of increase, and net reproductive rate) are appropriate indicators for evaluating the effect of host plants on the development, survival, and fecundity of different populations. The intrinsic rate of increase of this study was higher than that of De Conti et al. [15], but lower than that of Jandricic et al. [20]. The values under lower temperatures $\left(12.5\right.$ and $\left.15^{\circ} \mathrm{C}\right)$ in this study were lower and the values at 20 and $25^{\circ} \mathrm{C}$ were higher than those of Lee et al. [18]. The aphids may be impaired reproduction and produce few nymphs when fed on different host plant leaves containing low or high levels of soluble nitrogen [44-46]. This study presented the 
advantages of using the age-stage, two-sex life table theory in describing demography. We used survival rate and fecundity data to project the population growth of $A$. solani to show the advantage of using the age-stage, two-sex life table in revealing the stage structure of insect populations.

\section{Conclusions}

We investigated several characteristics of the development and reproduction of $A$. solani on soybean at 10 different temperatures, and described the relationship between temperature and this species' biology. Our results indicated that $A$. solani can survive and reproduce on soybean over a temperature range from 5 to $27.5^{\circ} \mathrm{C}$. High rates of reproduction occurred from 12.5 to $20^{\circ} \mathrm{C}$. The estimated LDT, UDT, and $T_{\text {opt }}$ for the nymphal development of this species were ca. $5.02{ }^{\circ} \mathrm{C}, 33.7^{\circ} \mathrm{C}$, and $26.9{ }^{\circ} \mathrm{C}$, respectively. The estimated total fecundity was ca. 76.9 nymphs per adult at $18.1^{\circ} \mathrm{C}$. Most models and their parameters used in this study fitted the observed data well. These models and the life table statistics derived herein should, however, be evaluated under conditions of fluctuating temperatures in the field or in field-simulating conditions before they are applied in future population dynamics studies.

Author Contributions: Conceptualization, J.K.J. and B.Y.S.; Methodology, J.K.J.; Validation, J.J.A. and Y.K.; Formal Analysis, J.K.J.; Investigation, B.Y.S. and E.Y.K.; Resources, S.K.; Writing-Original Draft Preparation, B.Y.S.; Writing-Review \& Editing, J.K.J. and J.J.A.; Visualization, J.K.J. and J.J.A.; Project Administration, J.K.J.; Funding Acquisition, J.K.J. All authors have read and agreed to the published version of the manuscript.

Funding: This research was funded by “Cooperative Research Program for Agriculture Science \& Technology Development (Project No. PJ01311602)", Rural Development Administration, Republic of Korea.

Acknowledgments: We are thankful I Hyeon Kim and Soon Il Bae for rearing plants and insects.

Conflicts of Interest: The authors declare no conflict of interest.

\section{References}

1. Holman, J. Host Plant Catalog of Aphids: Palaearctic Region; Springer: New York, NY, USA, 2009; pp. $175-185$.

2. Kim, D.-H.; Lee, G.-H.; Park, J.-W.; Hwang, C.-Y. Occurrence aspects and ecological characteristics of foxglove aphid, Aulacorthum solani, Kaltenbach (Homoptera: Aphididae) in soybean. Res. Rept. RDA 1991, 33, $28-32$.

3. Lee, J.S.; Yoo, M.; Jung, J.K.; Bilyeu, K.D.; Lee, J.-D. Detection of novel QTLs for foxglove aphid resistance in soybean. Theor. Appl. Genet. 2015, 128, 1481-1488. [CrossRef] [PubMed]

4. Takada, H.; Ono, T.; Torikura, H.; Enokiya, T. Geographic variation in esterase allozymes of Aulacorthum solani (Homoptera: Aphididae) in Japan, in relation to its outbreaks on soybean. Appl. Entomol. Zool. 2006, 41, 595-605. [CrossRef]

5. Hwang, C.Y.; Uhm, K.B.; Choi, K.M. Seasonal occurrence of aphids (Aulacorthum solani K., Aphis glycines M.) and effects of some insecticides on aphids with infurrow treatment in soybean. Korean J. Plant Prot. 1981, 20, 112-116.

6. Leather, S.R. Aspects of aphid overwintering (Homoptera: Aphidinea: Aphididae). Entomol. Gener. 1992, 17, 101-113. [CrossRef]

7. Lee, S.; Holman, J.; Havelka, J. Illustrated Catalogue of Aphididae in the Korean Peninsula. Part I. Subfamily Aphidinae (Hemiptera: Sternorrhyncha); KRIBB \& CIS: Chuncheon, Korea, 2002; pp. 106-108.

8. Miyazaki, M. Forms and morphs of aphids. In Aphids Their Biology, Natural Enemies and Control; Minks, A.K., Harrewijn, P., Eds.; Elsevier: New York, NY, USA, 1987; Volume A, pp. 27-50.

9. Turl, L.A.D. The effect of winter weather on the survival of aphid populations on weeds in Scotland. EPPO Bull. 1983, 13, 139-143. [CrossRef]

10. Honěk, A.; Kocourek, F. Temperature and development time in insects: A general relationship between thermal constants. Zool. Jahrbücher Syst. 1990, 117, 401-439.

11. Chown, S.L.; Nicolson, S.W. Insect Physiological Ecology: Mechanisms and Patterns; Oxford University Press: Oxford, UK, 2004; pp. 115-176.

12. Damos, P.; Savopoulou-Soultani, M. Temperature-driven models for insect development and vital thermal requirements. Psyche 2012, 2012, 1-13. [CrossRef] 
13. Dixon, A.F.G.; Honěk, A.; Keil, P.; Kotela, M.A.A.; Sizling, A.L.; Jarosik, V. Relationship between the minimum and maximum temperature thresholds for development in insects. Funct. Ecol. 2009, 23, 257-264. [CrossRef]

14. Wagner, T.L.; Wu, H.; Sharpe, P.J.H.; Coulson, R.N. Modeling distribution of insect development time: A literature review and application of Weibull function. Ann. Entomol. Soc. Am. 1984, 77, 475-483. [CrossRef]

15. De Conti, B.F.; Bueno, V.H.P.; Sampaio, M.V.; Sidney, L.A. Reproduction and fertility life table of three aphid species (Macrosiphini) at different temperatures. Rev. Bras. Entomol. 2010, 54, 654-660. [CrossRef]

16. De Conti, B.F.; Bueno, V.H.P.; Sampaio, M.V.; Van Lenteren, J.C. Development and survival of Aulacorthum solani, Macrosiphum euphorbiae and Uroleucon ambrosiae at six temperatures. Bull. Insectol. 2011, 64, 63-68.

17. Lee, S.G.; Kim, H.H.; Kim, T.H.; Park, G.-J.; Kim, K.H.; Kim, J.S. Development model of the foxglove aphid, Aulacorthum solani (Kaltenbach) on lettuce. Korean J. Appl. Entomol. 2008, 47, 359-364. [CrossRef]

18. Lee, S.G.; Kim, H.H.; Kim, T.H.; Park, G.-J.; Kim, K.H.; Kim, J.S. Longevity and life table of the foxglove aphid (Aulacorthum solani K.) adults on lettuce (Lactuca sativa L.). Korean J. Appl. Entomol. 2008, 47, 365-368. [CrossRef]

19. Park, G.-J. Temperature-dependent development and its model of the foxglove aphid, Aulacorthum solani (Kaltenbach) (Homoptera: Aphididae). Master's Thesis, JeonBuk National University, Jeonju, Korea, 22 August 2008.

20. Jandricic, S.E.; Wraight, S.P.; Bennett, K.C.; Sanderson, J.P. Developmental times and life table statistics of Aulacorthum solani (Hemiptera: Aphididae) at six constant temperatures, with recommendations on the application of temperature-dependent development models. Environ. Entomol. 2010, 39, 1631-1642. [CrossRef] [PubMed]

21. Kingsolver, J.G.; Higgins, J.K.; Augustine, K.E. Fluctuating temperatures and ectotherm growth: Distinguishing non-linear and time-dependent effects. J. Exp. Biol. 2015, 218, 2218-2225. [CrossRef]

22. Chi, H.; Liu, H. Two new methods for the study of insect population ecology. Bull. Inst. Zool. Acad. Sin. 1985, 24, 225-240.

23. Chi, H. Life-table analysis incorporating both sexes and variables development rates among individuals. Environ. Entomol. 1988, 17, 26-34. [CrossRef]

24. SAS Institute Inc. SAS/STAT 9.1 User's Guide; SAS Institute Inc.: Cary, NC, USA, 2004; pp. 1731-1906.

25. Campbell, A.; Frazer, B.D.; Gilbert, N.; Gutierrrez, A.P.; Markauer, M. Temperature requirements of some aphids and their parasites. J. Appl. Ecol. 1974, 11, 431-438. [CrossRef]

26. Lactin, D.J.; Holliday, N.J.; Johnson, D.I.; Craigen, R. Improved rate model of temperature-dependent development by arthropods. Environ. Entomol. 1995, 24, 68-75. [CrossRef]

27. Weibull, W.A. Statistical distribution function of wide applicability. J. Appl. Mech. 1951, 18, 290-293.

28. Eyring, H. The activated complex in chemical reactions. J. Chem. Phys. 1935, 3, 107-115. [CrossRef]

29. Curry, G.L.; Feldman, R.M. Mathematical Foundations of Population Dynamics; The Texas A\&M University Press: College Station, TX, USA, 1987; pp. 31-76.

30. Park, J.H.; Kwon, S.H.; Kim, T.O.; Oh, S.O.; Kim, D.-S. Temperature-dependent development and fecundity of Rhopalosiphum padi (L.) (Hemiptera: Aphididae) on corns. Korean J. Appl. Entomol. 2016, 55, 149-160. [CrossRef]

31. Briere, J.F.; Pracros, P.; LeRoux, A.Y.; Pierre, J.S. A novel rate model of temperature-dependent development for arthropods. Environ. Entomol. 1999, 28, 22-29. [CrossRef]

32. Kim, D.-S.; Lee, J.-H. Oviposition model of Carposina sasakii (Lepidoptera: Carposinidae). Ecol. Model. 2003, 162, 145-153. [CrossRef]

33. Sauvion, N.; Rahbé, Y.; Peumans, W.J.; Van Damme, E.J.M.; Gatehouse, J.A.; Gatehouse, A.M.R. Effects of GNA and other mannose binding lectins on development and fecundity of the peach-potato aphid Myzus persicae. Entomol. Exp. Appl. 1996, 79, 285-293. [CrossRef]

34. Ydergaard, S.; Enkegaard, A.; Brødsgaard, H.F. The predatory mite Hypoaspis miles: Temperature dependent life table characteristics on a diet of sciarid larvae, Bradysia paupera and B. tritici. Entomol. Exp. Appl. 1997, 85, 177-187. [CrossRef]

35. Birch, L.C. The intrinsic rate of natural increase of an insect population. J. Anim. Ecol. 1948, 17, 15-26. [CrossRef]

36. Southwood, T.R.E.; Henderson, P.A. Ecological Methods, 3rd ed.; Blackwell Science Ltd.: Oxford, UK, 2000; pp. 404-436. 
37. Chi, H. TWOSEX-MSChart: A Computer Program for the Age-Stage, Two-Sex Life Table Analysis. 2020. Available online: http://140.120.197.173/Ecology/Download/Twosex-MSChart.exe-B100000.rar (accessed on 19 April 2020).

38. Goodman, D. Optimal life histories, optimal notation, and the value of reproductive value. Am. Nat. 1982, 119, 803-823. [CrossRef]

39. Efron, B.; Tibshirani, R.J. An Introduction to the Bootstrap; Chapman \& Hall: New York, NY, USA, 1993; pp. 39-85.

40. Chi, H. TIMING-MSChart: A Computer Program for the Population Projection Based on Age-Stage, Two-Sex Life Table. 2020. Available online: http://140.120.197.173/Ecology/Download/Timing-MSChart.rar (accessed on 19 April 2020).

41. Pozarowska, B.J. Studies on low temperature survival, reproduction and development in scottish clones of Myzus persicae (Sulzer) and Aulacorthum solani (Kaltenbach) (Hemiptera: Aphididae) susceptible and resistant to organophosphates. Bull. Entomol. Res. 1987, 77, 123-134. [CrossRef]

42. Kikuchi, T.; Katoh, H.; Kagawa, K.; Sonoda, S.; Murai, T. Effects of high temperatures on development and fecundity of Aulacorthum solani (Homoptera: Aphididae) and Aphis glycines (Homoptera: Aphididae). Jpn. J. Appl. Entomol. Zool. 2018, 62, 41-46. [CrossRef]

43. Montllor, C.B.; Maxmen, A.; Purcell, A.H. Facultative bacterial endosymbionts benefit pea aphids Acyrthosiphon pisum under heat stress. Ecol. Entomol. 2002, 27, 189-195. [CrossRef]

44. Awmack, C.S.; Leather, S.R. Host plant quality and fecundity in herbivorous insects. Annu. Rev. Entomol. 2002, 47, 817-844. [CrossRef] [PubMed]

45. Atlihan, R.; Polat-Akkopru, E.; Ozgokce, M.S.; Kasap, I.; Chi, H. Population growth of Dysaphis pyri (Hemiptera: Aphididae) on different pear cultivars with discussion on curve fitting in life table studies. J. Econ. Entomol. 2017, 110, 1890-1898. [CrossRef] [PubMed]

46. Chen, G.-M.; Chi, H.; Wang, R.-C.; Wang, Y.-P.; Xu, Y.-Y.; Li, X.-D.; Yin, P.; Zheng, F.-Q. Demography and uncertainty of population growth of Conogethes punctiferalis (Lepidoptera: Crambidae) reared on five host plants with discussion on some life history statistics. J. Econ. Entomol. 2018, 111, 2143-2152. [CrossRef] [PubMed]

(C) 2020 by the authors. Licensee MDPI, Basel, Switzerland. This article is an open access article distributed under the terms and conditions of the Creative Commons Attribution (CC BY) license (http://creativecommons.org/licenses/by/4.0/). 